\title{
Genetic polymorphisms and cerebrovascular disease in children with sickle cell anemia from Rio de Janeiro, Brazil
}

\author{
Isaac Lima da Silva Filho', Ana Claudia Celestino Bezerra Leite ${ }^{2,4}$, \\ Patrícia Gomes Moura ${ }^{5}$, Georgina Severo Ribeiro ${ }^{6}$, Andréa Cony Cavalcante ${ }^{5}$, \\ Flávia Carolina Marques de Azevedo ${ }^{5}$, Maria José de Andrada-Serpa ${ }^{3}$
}

\begin{abstract}
The aim of the present work was to examine possible genetic risk factors related to the occurrence of cerebrovascular disease (CVD) in Brazilian population, the frequency of $\beta^{\mathrm{S}}$-globin gene haplotypes and co-inheritance with $\alpha$-thalassemia $\left(-\alpha^{3.7 \mathrm{~kb}}\right)$ and single nucleotide polymorphism of methylenetetrahydrofolate reductase (MTHFR-C677T), Factor V Leiden (FV-G1691A) and prothrombin (PT-G20210A) genes in children from Rio de Janeiro. Ninety four children with sickle cell anemia (SCA) were included, 24 patients with cerebrovascular involvement and 70 patients without CVD as control group. The mean age of children at the time of the cerebrovascular event was similar to the control group. The frequency of $-\alpha^{3.7 \mathrm{~kb}}$ thalassemia was similar in both groups $(p=0.751)$. Children with Bantu/Atypical $\beta^{\mathrm{S}}$-globin gene haplotype presented 15 times more chance $(\mathrm{OR}=15.4 \mathrm{Cl}$ $95 \%$ 2.9-81.6) of CVD than the other $\beta^{S}$-globin gene haplotypes. The C677T polymorphism of MTHFR gene was similar in both groups $(p=0.085)$. No mutation in the FV Leiden or PT genes was found. A large study seems necessary to establish the role of these genetic polymorphisms in Brazilian miscegenated population.

Key words: sickle cell anemia, cerebrovascular disease, alpha-thalassemia, beta-globin haplotypes, genetic polymorphism.
\end{abstract}

Polimorfismos genéticos e doença cerebrovascular em crianças com anemia falciforme do Rio do Janeiro, Brasil

\section{RESUMO}

Avaliar o papel da talassemia alfa $\left(-\alpha^{3.7 k b}\right)$, dos haplótipos da globina $\beta^{S}$, e mutações nos genes da metileno-tetrahidrofolato redutase (MTHFR-C677T), fator $V$ de Leiden (FVG1691A) e protrombina (PT-G20210A) como fatores de risco para a doença cerebrovascular em pacientes com anemia falciforme. Foi realizado um estudo de caso controle com 94 crianças portadoras de anemia falciforme, 24 com doença cerebrovascular (DCV) e 70 sem DCV como grupo controle. A frequência de talassemia $-\alpha^{3.7 \mathrm{~kb}}$ foi semelhante em ambos os grupos $(p=0,751)$. Crianças portadoras do haplótipo Bantu/Atípico da globina $\beta^{S}$ apresentam 15 vezes mais chances de desenvolverem DCV (OR=15,4 IC 95\% 2,9-81,6) do que os outros haplótipos. A frequência do polimorfismo MTHFR-C677T foi semelhante em

\section{Correspondence}

Isaac Lima da Silva Filho Laboratório de Pesquisa em Patogenia Viral / Instituto de Pesquisa Clínica Evandro Chagas / Fundação Oswaldo Cruz Av. Brasil 4365 21045-900 Rio de Janeiro RJ - Brasil E-mail: filho40@gmail.com

Received 6 May 2010 Received in final form 2 March 2011 Accepted 14 March 2011 ambos os grupos $(p=0,085)$ e não foi observada mutação nos genes fator $V$ e protrombina. Estudos com maior número de casos são necessários para esclarecer o papel desses polimorfismos genéticos na nossa população.

Palavras-chave: anemia falciforme, acidente vascular cerebral, talassemia alfa, globinas beta, polimorfismo genético.

'BSc, MSc, PhD, Instituto de Pesquisa Clínica Evandro Chagas, Fundação Oswaldo Cruz, Rio de Janeiro RJ, Brazil; ${ }^{2} \mathrm{MD}, \mathrm{MSc}$, $\mathrm{PhD}$, Instituto de Pesquisa Clínica Evandro Chagas, Fundação Oswaldo Cruz, Rio de Janeiro RJ, Brazil; ${ }^{3} \mathrm{MD}$, PhD, Instituto de Pesquisa Clínica Evandro Chagas, Fundação Oswaldo Cruz, Rio de Janeiro RJ, Brazil; ${ }^{4} \mathrm{MD}$, MSc, PhD, Instituto Estadual de Hematologia Arthur de Siqueira Cavalcante, Rio de Janeiro RJ, Brazil; ${ }^{5} \mathrm{MD}$, Instituto Estadual de Hematologia Arthur de Siqueira Cavalcante, Rio de Janeiro RJ, Brazil; ${ }^{6} \mathrm{MD}, \mathrm{MSc}, \mathrm{PhD}$, Universidade Federal Fluminense, Niterói RJ, Brazil. 
Sickle cell anemia (SCA) is a genetic disorder caused by homozygosity for a single $\beta$-globin gene mutation $\left(\beta^{6} \mathrm{GAG} \rightarrow \mathrm{GTG}\right)$, in which glutamic acid has been substituted for valine at the sixth codon of $\beta$-globin chain. Despite this fact, the clinical course of patients suffering from SCA is extremely variable, the severity of manifestations ranging from asymptomatic to a very severe course $^{1,2}$. The phenotypic variability maybe explained by some genetic factors, those related to globin genes have been well recognized ${ }^{2}$. There is evidence that SCA and other chronic hemolytic anemia are characterized by a hypercoagulable state with increased of thrombin and fibrin generation as well as platelet activation with an augmented risk for thromboembolic complications ${ }^{3}$.

Cerebrovascular disease (CVD) is a major complication of sickle cell disease ${ }^{4}$. Stroke is a very severe event and is estimated that approximately $11 \%$ of patients will have a clinical stroke by age $20^{2,4}$, and $21 \%$ have evidence of silent infarction on magnetic resonance imaging ${ }^{5}$. CVD is more frequent among patients with SCA than patients with sickle cell disease, and approximately $10 \%$ of children between the ages of 2 to 16 years are at risk for stroke $e^{4,6}$, the incidence is higher in the 1 to 9 years ${ }^{4}$.

Anemia, high leukocytes count, high blood pressure and acute chest syndrome are risk factors for the development of CVD in sickle cell disease ${ }^{2}$. A familial predisposition to stroke has been observed, suggesting that genetic factors may contribute to CVD risk ${ }^{7}$. Fetal hemoglobin $(\mathrm{HbF})$ and $\beta^{\mathrm{S}}$-globin haplotypes are the most studied genetic modulator for SCA, but the diversity of the disease is not completely explained by this modulation, and several potential genetic modifiers have been studied. These candidate genes include mediators of inflammation, vaso-regulation, blood coagulation, haemostasis, growth factors, cytokines and cytokine receptors, and transcriptional factors ${ }^{8}$. Furthermore, the C677T polymorphism in methylenetetrahydrofolate reductase gene as well as Factor V Leiden (FV-G1691A) and prothrombin (PT-G20210A) have been implicated in vascular diseases ${ }^{8}$. Despite the recent studies indicating probable genetic factors, only few have been recognized to influence the risk of stroke in $\mathrm{SCA}^{1}$.

To examine possible genetic risk factors related to the occurrence of CVD in a group of Brazilian patients, the frequency of $\beta^{\mathrm{S}}$-globin gene haplotypes and co-inheritance with $\alpha$-thalassemia $\left(-\alpha^{3.7 k b}\right)$ and single nucleotide polymorphism in methylenetetrahydrofolate reductase (MTHFR-C677T), Factor V Leiden (FV-G1691A) and prothrombin (PT-G20210A) genes were determined in children with SCA followed at the Instituto Estadual de Hematologia Arthur de Siqueira Cavalcanti, Rio de Janeiro.

\section{METHOD}

After review by local Institutional Ethics Boards and informed consent signed by parent or guardian, blood samples from 94 children with SCA were collected and genomic DNA was extracted from peripheral blood mononuclear cells using a commercial kit (Puregene ${ }^{\circ}$ DNA Purification System-Gentra). Twenty four children were randomly selected from a cohort of patients that have had CVD, and 70 children were randomly selected from clinic records of the neonatal hemoglobinopathy screening program of the state of Rio de Janeiro, Brazil. The children without CVD were matched by sex and closest in age at the time of the cerebrovascular event to the index cases. Cerebrovascular disease was defined by the presence of: [a] stroke with resultant ischemia and neurologic symptoms or signs for more than 24 hours plus abnormal brain computed tomography or magnetic resonance imaging, or $[\mathrm{b}]$ transient ischemic attacks for less than 24 hours plus abnormal brain computed tomography or magnetic resonance imaging, or [c] transcranial Doppler with highest time-averaged mean of the maximum velocity in middle cerebral artery, distal internal carotid artery, anterior cerebral artery and bifurcation, velocities greater than $200 \mathrm{~cm} / \mathrm{sec}$, according to the STOP trial ${ }^{6,9}$.

The $\beta^{\mathrm{S}}$-globin gene cluster haplotype (Bantu or CAR [Central African Republic] Benin, Senegal, Arab-Indian and Atypical) was determined by polymerase chain reaction (PCR) followed by restriction fragment length polymorphism (RFLP). A pattern of six polymorphic restriction sites was identified within the beta-globin gene complex $\left(5^{\prime} \gamma^{G}, \gamma^{G}, \gamma^{A}, \psi \beta, 3^{`} \psi \beta, 5^{\prime} \beta\right)$. Products were digested with restriction endonucleases for polymorphisms identification $\left(X m n I\left[5^{\prime} \gamma^{G}\right]\right.$, HindIII $\left[\gamma^{G}\right]$, HindIII $\left[\gamma^{\mathrm{A}}\right]$, HincII $[\psi \beta], \operatorname{HincII}\left[3^{\prime} \psi \beta\right]$, Hinfl [ $\left.\left.5^{\prime} \beta\right]\right)$, according to Sutton et al. ${ }^{10}$.

The $\alpha$-thalassemia $\left(-\alpha^{3.7 k b}\right)$ single gene deletion was detected by PCR, primers were designed to amplify the junction fragments of the $\alpha$-thalassemia determinants that could be easily identified by size. Since of the $-\alpha^{3.7 k b}$ deletions partially remove both $\alpha$-genes, the positive amplification was used to indicate heterozygosity when a deleted allele was also present ${ }^{11}$. The C677T mutation in the MTHFR gene, G1691A in FV Leiden and G21210A in prothrombin gene were determined by PCR-RFLP according to the methods described by Frosst et al. ${ }^{12}$, Zöller and Dahlbäck. ${ }^{13}$ and Poort et al. ${ }^{14}$, respectively. The MTHFR C677T mutation, primers generate a fragment of $198 \mathrm{bp}$, the substitution creates a Hinf I recognition sequence which digests the $198 \mathrm{bp}$ fragment into 175 and $23 \mathrm{bp}$ fragments. The region in exon 10 of the factor $\mathrm{V}$ gene was amplified the $161 \mathrm{bp}$ amplicon obtained was subjected to $M n l 1$ digestion, which produced frag- 
ments of 43 and $118 \mathrm{bp}$. A 345-bp fragment from exon 14 and the 3'-UT region of the prothrombin gene was amplified. A new Hind lll site (-A/AGCTT-) was introduced in the amplified fragments from the less-frequent allele ( $\mathrm{A}_{2}$ : $\mathrm{AAG}$ ) yielding two fragments (322 bp and $23 \mathrm{pb}$ in length) after enzyme digestion. The more frequent allele $\left(\mathrm{A}_{1}: \mathrm{GAG}\right)$ lacks the restriction site and therefore generates only a 345-bp fragment by PCRHindlll digestion.

Analyses were performed using SPSS (Statistics Package for Social Science). Comparison of categorical data was done by chi-square test, including odds ratios (OR) and $95 \%$ confidence interval (CI), t-student test was used to compare age mean between the groups and $\mathrm{p}$ values $\leq 0.05$ were considered significant.

\section{RESULTS}

Ninety four children ( 48 boys and 46 girls) were included, with a mean age of 6.6 years (range from 3.2 to 15 years), 24 (13 boys and 11 girls) patients with cerebrovascular involvement were participating in regular blood transfusion program, and 70 ( 35 boys and 35 girls) patients with normal transcranial Doppler and no CVD. The mean age of children at the time of the diagnosis of CVD was 5.1 years $( \pm$ SD 1.4 years $)$ and of 5.4 years $( \pm$ SD 1.6 years) for the control group ( $\mathrm{p}=0.53$ ).

The frequency of $\alpha$-thalassemia $\left(-\alpha^{3.7 k b}\right)$ in the group with cerebrovascular disease was of $15.8 \%$ (3/19) compared to $22.4 \%(15 / 67)$ in the controls $(\mathrm{p}=0.751)$.

Table shows molecular characteristics of children according to the presence of CVD. In eight patients, $\alpha$-chain fragment was not amplified, and in four out of these eight, the $\beta^{\mathrm{S}}$-globin haplotype could not be genotyped, probably due to DNA quality.

The number of children with CVD was higher $\left(x^{2}=16.8\right.$ and $\left.p=0.001\right)$ among those with Bantu/Atypical than the ones with Bantu/Bantu and Bantu/Benin haplotypes (Table). Children with Bantu/Atypical haplotype presented 15 times more chance (OR=15.4 [CI 95\% 2.9-81.6]) of cerebrovascular involvement than the other $\beta^{\mathrm{S}}$-globin gene haplotypes (Table).

The C677T polymorphism of MTHFR gene was found in 37.5\% (9/24) of children with CVD and in $20 \%(14 / 70)$ of the control group $\left(x^{2}=2.9\right.$ and $\left.p=0.085\right)$. This polymorphism was found in $23 \%$ of patients (23/94) and, four children were homozygous for the mutation, while 15 were heterozygous. None of the four homozygous children presented cerebrovascular involvement. No mutation in the FV Leiden or PT genes was found.

\section{DISCUSSION}

Stroke is a catastrophic event and represents the second ( 10\%) leading cause of death in both adult and children ${ }^{4}$. During the last decades, several attempts have been made to detect genetic modifiers of the clinical course in $\mathrm{SCA}^{1,2}$, as well as genetic polymorphisms implicated in the occurrence of cerebrovascular disease. Despite all the effort, very few genes have been related to the clinical course of SCA. This report represents the first study of genetic factors and CVD in a group of Brazilian SCA patients.

Table. Molecular characteristics of patients according to the presence of cerebrovascular disease.

\begin{tabular}{|c|c|c|c|c|c|}
\hline \multirow[b]{2}{*}{ Molecular characteristics } & \multicolumn{2}{|c|}{ Cerebrovascular disease } & \multirow[b]{2}{*}{ Total } & \multirow[b]{2}{*}{$X^{2}$} & \multirow[b]{2}{*}{$\mathrm{p}$} \\
\hline & Present n (\%) & Absent n (\%) & & & \\
\hline BS-globin haplotype & & & & 15.4 & $0.001^{\#}$ \\
\hline Bantu/Bantu & $11(50)$ & $36(52.9)$ & 47 & & \\
\hline Bantu/Atypical & $7(31.8)$ & $2(2.9)$ & 9 & & \\
\hline Bantu/Benin & $4(18.2)$ & $30(44.1)$ & 34 & & \\
\hline Total & 22 & $68^{*}$ & $90^{*}$ & & \\
\hline$-\alpha^{3.7 \mathrm{~kb}}$ thalassemia & & & & 0.38 & 0.751 \\
\hline Present & $3(15.8)$ & $15(22.4)$ & 18 & & \\
\hline Absent & $16(84.2)$ & $52(77.6)$ & 68 & & \\
\hline Total & 19 & 67 & $86^{* *}$ & & \\
\hline MTHFR C677T & & & & 2.96 & 0.085 \\
\hline Present & $9(37.5)$ & $14(20)$ & 23 & & \\
\hline Absent & $15(62.5)$ & $56(80)$ & 71 & & \\
\hline Total & 24 & 70 & 94 & & \\
\hline
\end{tabular}

$x^{2}$ Pearson Chi-square; "Bantu/Atypical versus Bantu/Bantu and Bantu/Benin; *In four patients $\beta$ S-globin haplotype was not done due to degraded DNA; **Eight patients were not typed for $\alpha$-thalassemia due to degraded DNA; MTHFR: methylenetetrahydrofolate reductase. 
Several studies showed that the incidence of CVD for SCA patients with $\alpha$-thalassemia is lower than that for patients without $\alpha$-thalassemia ${ }^{4,15,16}$.

In our results, the frequency of thalassemia was lower among patients with CVD, but with no significant difference when compared to the ones without cerebrovascular involvement. Furthermore, only $15.8 \%$ had $\alpha$-thalassemia compared to the reported prevalence of 20 to $25 \%$ in Afro-Brazilian population with $\mathrm{SCA}^{17}$.

An increased $\mathrm{HbF}$ concentration can ameliorate SCA severity. Individual $\mathrm{HbF}$ variation is largely genetically controlled, with at one side caused by mutations of the globin gene complex, named hereditary persistence of fetal hemoglobin and at the other side, recently identified three major quantitative trait loci (QTLs). The first known QTL is the Xmn1-HBG2 site at the gamma-globin gene, and now joined by two other loci: $H B S 1 L-M Y B$ intergenic region $6 \mathrm{q}$ and $B C L 11 A$. Common polymorphisms at the three QTLs strongly affect HbF levels in healthy individuals and patients with hemoglobinopathies and account for relatively large proportion (20-50\%) of $\mathrm{HbF}$ levels variation ${ }^{18}$. SCA patients have $\mathrm{HbF}$ levels ranging from 1 to $30 \%$, concerning the role of $\beta^{S}$-globin haplotypes on clinical severity. Carriers of the Senegal or Arab-Indian haplotypes have the highest HbF levels and a mild clinical course, and individuals with Bantu haplotypes the lowest HBF levels ${ }^{8}$.

Regarding $\beta^{S}$-globin haplotypes and cerebrovascular disease the studies have been conflicting. Sarnaik and Ballas ${ }^{15}$ reported that the presence of at least one Bantu and/or atypical haplotype increases the risk for CVD. Kinney et al. ${ }^{19}$ described that silent cerebral infarcts in SCA were related to Senegal haplotype. On the other hand, Bernaudin et al. ${ }^{20}$ reported no influence of $\beta^{S}$ globin haplotypes on the presence of abnormal high cerebral velocities by transcranial Doppler in patients with SCA. Adorno et al. ${ }^{21}$ in Salvador, Brazil, described in 5 cases with CVD the presence of at least one Bantu haplotype. Our results suggest that the presence of Bantu/ Atypical haplotype is a risk factor for CVD.

The role of hyperhomocysteinemia as a potential risk for cerebrovascular disease is still controversial ${ }^{22}$. The most common polymorphism associated with raised homocysteine level is the C-to-T substitution at nucleotide 677 of the gene methylenetetrahydrofolate reductase, and the relationship of this mutation with vascular diseases have been described in some population ${ }^{23}$. This study failed to demonstrate a positive relationship between the presence of C677T MTHFR polymorphism and CVD in SCA patients. Same results have been reported by Cumming et al. ${ }^{24}$. Furthermore, caution is needed in the asserting that this genetic polymorphism played a role in the occurrence of cerebrovascular disease in SCA, as none of cerebrovascular patients presented homozygosity for the MTHRF polymorphism.

According to previous report factor $\mathrm{V}$ Leiden (G1691A) mutation was found at high frequency in Caucasian (5.27\%), and lower prevalence in Hispanic (2.21\%) and Afro-Americans (1.23\%) ${ }^{25}$. The prothrombin (G20210A) mutation is present in $1.1 \%$ of Caucasian Americans and in a very low frequency in Afro-descendants $(0.3 \%)^{26}$. Both genetic polymorphisms are rare in Afro-descendants. In Brazil, reports described a low frequency in general population, ranging from 1-2\% for FVG1691A and 0.7-3.6\% for PT-G20210A ${ }^{27-29}$. Only two papers described the frequency of these polymorphisms in SCD. Andrade et al. ${ }^{27}$ found a frequency of $2.73 \%$ for both genes mutation (2 out of 73 patients), and Couto ${ }^{29}$ et al. failed to find PT-G20210A variant in SCA patients from the Northeast of Brazil. The difference observed between these reports maybe due to the origin of patients, in São Paulo the significant contribution of European immigrants in the population formation may explain these findings. It is necessary a large study, including in different Brazilian regions to reach a more precise prevalence of these polymorphisms.

This is the first genetic study carried out in children with SCA and cerebrovascular involvement in Brazil, a large study seems necessary to establish the real role of these genetic polymorphisms in our very miscegenated population.

\section{REFERENCES}

1. Steinberg $\mathrm{MH}$, Adewoye $\mathrm{AH}$. Modifier genes and sickle cell anemia. Curr Opin Hematol 2006;13:131-136.

2. Adams GT, Snieder H, McKie VC, et al. Genetic risk factors for cerebrovascular disease in children with sickle cell disease: design of a case-control association study and genome wide screen. BMC Medical Genetics 2003;4:6.

3. Ataga KI, Orringer EP. Hypercoagulability in sickle cell disease: a curious paradox. Am J Med 2003;115:721-728.

4. Ohene-Frempong KO, Weiner SJ, Sleeper LA, et al. Cerebrovascular accidents in sickle cell disease: rates and risk factors. Blood 1998;91:288-294.

5. Pegelow CH, Macklin EA, Moser FG, et al. Longitudinal changes in brain magnetic resonance imaging findings in children with sickle cell disease. Blood 2002;99:3014-3018.

6. Adams JR. Big strokes in small persons. Arch Neurol 2007;64:1567-1574.

7. Driscoll MC, Hurlet A, Styles L, et al. Stroke risk in siblings with sickle cell anemia. Blood 2003;101:2401-2404.

8. Steinberg MH. Predicting clinical severity in sickle cell anaemia. Br J Haematol 2005;129:465-481.

9. Adams RJ, McKie VC, Hsu L, et al. Prevention of a first stroke by transfusions in children with sickle cell anemia and abnormal results on transcranial Doppler ultrasonography. N Engl J Med 1998;339:5-11.

10. Sutton M, Bouhassira EE, Nagel RL. Polymerase chain reaction amplification applied to the determination of beta-like globin cluster haplotypes. Am J Hematol 1989;32:66-69.

11. Chong SS, Boehm CD, Higgs DR. et al. Single-tube multiplex-PCR screen for common deletional determinants of $\alpha$-thalassemia. Blood 2000;95:360-362.

12. Frosst T, Blom HJ, Milos R, et al. A candidate genetic risk factor for vascular disease: a common mutation in methylenetetrahyfolate reductase. Nat Genet 1995;10:111-113.

13. Zöller B, Dahlbäck B. Linkage between inherited resistance to activated protein $C$ and factor $V$ gene mutation in venous thrombosis. Lancet 1994; 343:1536-1538. 
14. Poort SR, Rosendal FR, Reitsma PH, Bertina RM. A common genetic variation in the $3^{\prime}$-unstraslated region of the prothrombin gene is associated with elevated plasma prothrombin levels and increase in venous thrombosis. Blood 1996;88:3698-3703.

15. Sarnaik SA, Ballas SK. Molecular characteristics of pediatric patients with sickle cell anemia and stroke. Am J Hematol 2001;67:179-182.

16. Neonato MG, Guilloud-Bataille M, Beauvais $P$, et al. Acute clinical events in 299 homozygous sickle cell patients living in France. French Study Group on Sickle Cell Disease. Eur J Haematol 2000;65:155-164.

17. Wenning MR, Kimura EM, Costa FF, et al. $\alpha$-Globin genes: thalassemic and structural alterations in a Brazilian population. Braz J Med Biol Res 2000; 33:1041-1045.

18. Menzel S, Thein SL. Genetic architecture of hemoglobin F control. Curr Opin Hematol 2009;16:179-186.

19. Kinney TR, Sleeper LA, Wang WC, et al. Silent cerebral infarcts in sickle cell anemia: a risk factor analysis. Pediatrics 1999;103:640-645.

20. Bernaudin F, Verlhac S, Chevret S. G6PD deficiency, absence of \{alpha\}thalassemia, and hemolytic rate at baseline are significant independent risk factors for abnormally high cerebral velocities in patients with sickle cell anemia. Blood 2008;112:4314-4317.

21. Adorno EV, Zanette AL, Lyra I, et al. Clinical and molecular characteristics of sickle cell anemia in the northeast of Brazil. Genetics Mol Biol 2008;31:621-625.

22. Homocysteine Studies Collaboration. Homocysteine and risk of ischemic heart disease and stroke. JAMA 2002;288:2015-2021.
23. Goracy I, Cyryłowski L, Kaczmarczyk M, et al. C677T polymorphism of the methylenetetrahydrofolate reductase gene and the risk of ischemic stroke in Polish subjects. J Appl Genet 2009;50:63-67.

24. Cumming AM, Olujohungbe A, Keeney S, Singh $H$, Hay CR, Serjeant GR. The methylenetetrahydrofolate reductase gene C677T polymorphism in patients with homozygous sickle cell disease and stroke. Br J Haematol 1999:107:569-571.

25. Ridker PM, Miletich JP, Hennekens CH, Buring JE. Ethnic distribution of Factor V Leiden in 4047 Men and women: implications for venous thromboembolism screening. JAMA 1997; 277:1305-1307.

26. Segal JB, Brotman DJ, Necochea AJ, et al. Predictive value of Factor $V$ leiden and prothrombin G20210A in adults with venous thromboembolism. JAMA 2009:301:2472-2485.

27. Andrade FL, Annichino-Bizzacchi AJM, Saad ST, Costa FF, Arruda VR. Prothrombin mutant, Factor $V$ Leiden and thermolabile variant of methylenetetrahydrofolate reductase amog patients with sickle cell disease in Brazil. Am J Hematol 1998;59:46-50.

28. Neto FM, Lourenço DM, Noguiti MAE, et al. The clinical impact of MTHFR polymorphisms on the vascular complications of sickle cell disease. Braz Med Biol Res 2006:39:1291-1295.

29. Couto FD, Vilas Boas W, Lyra I, et al. A C677T methylenetetrahydrofolate reductase (MTHFR) polymorphisms and G20210A mutation in the prothrombin gene of sickle cell anemia patients from Northeast Brazil. Hemoglobin 2004;28:237-241. 